\title{
シリーズ：内科医と災害医療
}

\section{アクションカード避難所編改訂 一東日本大震災の教訓を受けて一}

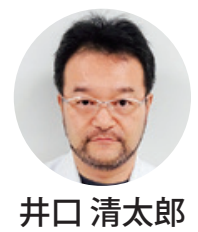

〔日内会誌 105：2259～2262，2016〕

\section{はじめに}

サバイバルカード・アクションカードの改訂 についてはこれまで別稿で書かれてきた通りで ある.今回の改訂では, 避難所という場におい てDMAT（Disaster Medical Assistance Team）の 受け入れ，急性期の立ち上げから慢性期，集約 化・撤退に至るまで同一の現場における経時的 な役割の変化を踏まえた形式とした。

また，災害と一言でいっても，その様態は幅 広く, 求められる医療も様々であろう。しかし, 本稿では, その中でも内科医として, 特に避難 所を現場として関わる際に，最低限おさえてお きたいエッセンスなどをまとめて記載した。こ のアクションカードが必要となる現場は限られ た環境下であると思われるし，このアクション カードを使うような状況にある医師は限られた 者であろう。だが, 過日発生した熊本地震は, 日本という国にあって地震災害が起きないと断 言できる場所などどこにもないことを知らしめ
た。全ての医師が状況によってはこれを必要と する現場にいる可能性があるともいえる.

また，避難所で実際に救護所を立ち上げる際 に，過去の経験をもつ医師は多くない。日本内 科学会専門医部会災害医療ワーキンググルー プは新潟県中越地震, 中越沖地震を経て, 2010 年よりシリーズ「内科医のための災害医療活 動」の連載を行ってきた. 本稿は, その中でも 特に医療支援編 (避難所編 $)^{11}$ を参考にしつつ, 東日本大震災の経験も踏まえて改訂し，作成し た。本シリーズが現場において救護所を立ち上 げる際に必要なこと, 引き継いでいく際に考え るべきこと，対応する際におさえておきたい疾 患, 病態についても網羅するよう配慮した。殊 に，重要な事項については赤色で示した。

\section{1. 避難所編一救護所立ち上げ（1）（2）}

発災直後に災害規模や自身の周辺地域の被害 状況を把握することは，どのような災害であっ 
てもまず必要なことである，また，自身が所属 する組織がどのような性格をもつ組織なのかを 認識することも必要である.すなわち災害医療 病院なのか, 地域の診療所（個人か公的機関か） なのか, 人的資源をどの程度有する組織なのか によって，その後とるべき対応が異なってく る. 当初, 最も必要なことは救護所設置の是非 と行政との連携である. 救護所も継続していく ためには行政との連携は必須であり, 単独では 存立し得ないからだ. 行政組織と連携すること で，必要な物資・人員の継続的な確保にもつな がり，災害に特化した救援隊であるDMATとの 連携も図れる。また，ライフラインに関する情 報も重要となるだろう。救護所で活動していく 際に診療の継続性を担保するためには診療録の 作成は必須といえる. 電気やネット回線など通 信関連インフラの被害状況にも左右されるが, 紙媒体や，場合によってはパソコン上に記録で きる形式のものでもよいだろう.

\section{2. 避難所編一トリアージ・DMAT対応}

ここではトリアージについて触れた。すでに トリアージの実際については多くの文献で触れ られていると思うが, 重要なものでもあり, 改 めて再掲する.また, START (simple triage and rapid treatment）法によるトリアージのフロー チャートを図に示す. 救助者に比し, 負傷者が 極端に多いときなどに用いて，一人おおむね 30 秒程度で判断する。 もちろん, 全ての状況に当 てはまるものではないが，繁用されている．実 際に用いる場合には直接治療に関与しない専任 の医療従事者が行うとされている。また, 可能 な限り, 繰り返し行うことが推奨されている.

\section{3. 避難所編一DMAT・急性疾患対応}

発災当日から 1 週間程度までを考慮し, 着目 すべき病態について列挙した。発災の初期に
あって，これまでの医療を継続する必要のある 人を見逃してはならない. 具体的には在宅酸素 療法者, 透析患者, インスリン自己注射の患者 などであり，これらは数日のうちに対処方針を 決定する必要があり。また, それ以降では慢性 疾患でも治療が中止されることで急速に悪化し ていく疾患を挙げた。特に薬物治療が行われて いる糖尿病, 心不全, 高血圧などは治療の継続 が必須であり, 内服薬の中止は意図せぬ重大な 結果を生じることがある.

発災して 1 週間以上経過した時期になると， 感冒や肺炎, さらには不安やそれに起因する不 眠，食欲不振などが顕在化してくる，避難所環 境への配慮が求められ始める時期でもある.

\section{4. 避難所編一慢性疾患・その他対応}

避難所で患者を診るときに，外傷を中心に診 る時期は初期に集中しており，その後は慢性疾 患に対する内科的な対応が求められるようにな る. 本編では, 発災後の時期によって着目すべ き慢性疾患などについて記載した。まず，発災 のごく早い段階で対応を要する病態を挙げてお り，これらは避難所で患者が来るのを待つだけ でなく，能動的に拾い上げることを要する．特 に内服薬を持ち出せずに避難してきた患者は要 注意である. 数日の内服中止では直ちに影響は ないものの, 長期的な避難生活の中で問題とな る疾患もあり,これらは留意する必要がある。 患者の中には内服を中止しても, 大きな問題が ないと考えている場合もあり, 災害時故にわが ままを言ってはならないと考えている者もい る.医療者から率先してこれらの患者を能動的 に拾い上げ，内服継続の必要性を伝えていくこ とも重要な役割である.

災害発生後のストレスなどにより災害発生後 2〜4週間までは血圧が上昇することが知られ ており2), 実際に脳卒中や心不全など循環器系 の疾患が発災直後から約 3 力月にわたって増 


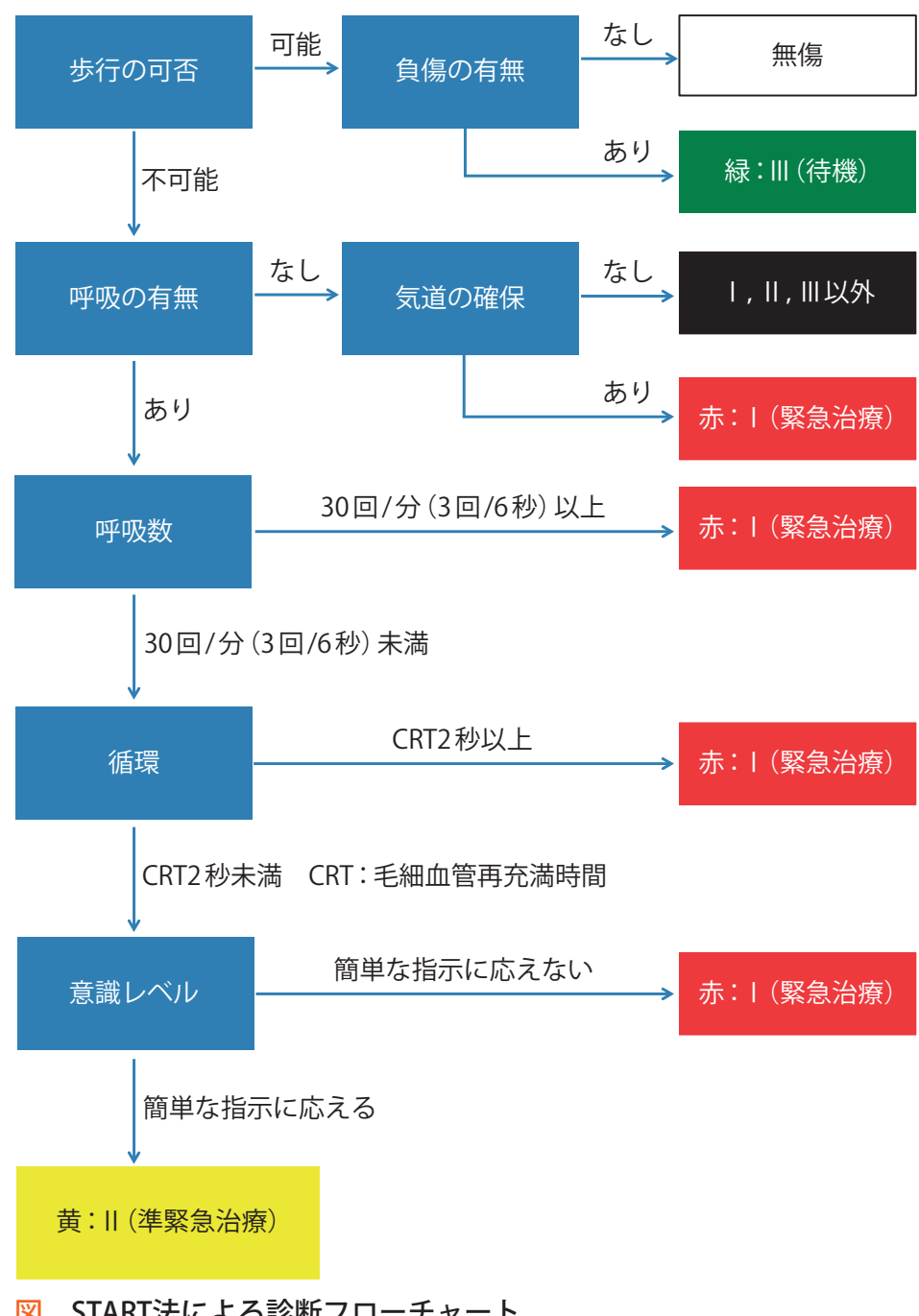

図 START法による診断フローチャート

加・遷延したことが知られている3). また，集 団生活が長引く中で, 感染症の発症は最も懸念 されるところである。災害の発生した季節に よっては，インフルエンザなど特に注意する必 要があろう。東日本大震災では避難所における 徹底的な感染症対策支援, マニュアル作成によ る情報の共有化などを行うことで, 効果的に感 染症マネジメントを行うことができた4). 今後 の災害医療においても参考になると思われる。

元来, 健康な者であっても長期的な避難所と いう集団生活の中で問題が起きてくる場合があ
り, これらについても留意する. 特に生活不活 発病は高齢者において気をつけるべき病態であ る. 東日本大震災では震災 7 力月後に南三陸町 で行われた全町民の生活機能に関する調査にお いて, 非要介護認定高齢者の $23.9 \%$ に歩行困難 が出現し, 回復しないままであったことが知ら れている5). 特に避難所や仮設住宅ではその頻 度が高いとされており, 医療者はそのことを踏 まえて対応していかなければならない. 


\section{5. 避難所編一救護所撤収}

救護所を開設する際には，必ず始まりがあれ ば終わりがあることを認識していかなければな らない。避難所があり続ける限り, 救護所を設 置し続けることは必ずしも正しいことではな い。また，災害によって，その地域の平時より もさらに医療が充実している状況を長引かせる ことは, 最終的に地域の医療にとって資するこ とにはならない可能性がある. 救護所の集約 化・撤退については, 常にその可能性に留意し ながら見極めていくことが求められる. 東日本 大震災で町内の全ての医療機関が壊滅的な被害 を受けた南三陸町では, 震災からわずか 2 力月 足らずで全国の医療支援チームの撤退を完了さ せた ${ }^{6)}$. もちろん今後, 起こり得る全ての災害 に適用することはできないが，その撤退の目安 （医療の安定化, 地元医療機関の再開, 通院方法 の確保）や，その後のきめ細やかな経過観察体 制については参考になるところが多い.

\section{おわりに}

世界一の超高齢社会にある日本にあって, 災 害医療もまた，他国のそれとは異なる視点をも たざるを得ない，災害医療は外傷などへの対応 だけでなく, 内科医としての視点をもち, 活動 するとともに公衆衛生的な対応も必要とされ る。特に避難所編では公衆衛生的な視点が重要 である。もはや，医療職が単独でなし得るもの ではなく，行政に関わる多くの人たちと連携 し，危機的状況に対応していかなければならな い. 災害医療に関わる医師には医療だけでな く，地域社会を俯瞰することが求められる，来 たるべき災害への医療対応に本稿が資すること を願っている。

著者のCOI（conflicts of interest）開示：井口清太郎；寄 附講座 (新潟県)

1）藤田俊夫：医療支援編（避難所編）。日内会誌 $99: 2604-2606,2010$.

2) 䓭尾七臣：災害時の循環器疾患：内科診療の留意点. 日内会誌 101: 1446-1457, 2012.

3）下川宏明：3. 東日本大震災から学ぶ内科疾患〜特徵, 対応, 予防〜1) 東日本大震災と循環器疾患. 日内会誌 103 : 545-550, 2014.

4）賀来満夫：3. 東日本大震災から学ぶ内科疾患～特徵, 対応, 予防～5）感染症. 日内会誌 $103: 572-580,2014$.

5）大川弥生：生活不活発病の予防と回復支援一「防げたはずの生活機能低下」の中心課題. 日内会誌 102：471-477, 2013.

6）西澤匡史：南三陸町における災害医療. 日内会誌 101：1136-1140, 2012. 